Journal of Sustainable Development of Transport and Logistics

journal home page: https://jsdtl.sciview.net

Elem, T. R., Ogwude, I. C., Ibe, C. C., Nnadi, K. U., \& Ejem, E. A. (2020). Decoupling of

economic activity and freight transport volume: An evidence for short sea shipping future

in the ECOWAS sub-region. Journal of Sustainable Development of Transport and Logistics, 5(2), 124-134. doi:10.14254/jsdtl.2020.5-2.11.

\title{
Decoupling of economic activity and freight transport volume: An evidence for short sea shipping future in the ECOWAS sub- region
}

\author{
T. R. Elem *, I. C. Ogwude **, C. C. Ibe ${ }^{* *}$, K. U. Nnadi ${ }^{* *}$, Ejem A. Ejem **iD \\ * Nigeria Maritime Administration and Safety Agency (NIMASA), Apapa, Lagos \\ ** Department of Transport Management Technology, Federal University Technology, Owerri, Nigeria \\ *** Department of Maritime Management Technology, Federal University of Technology, Owerri, Imo State, Nigeria
}

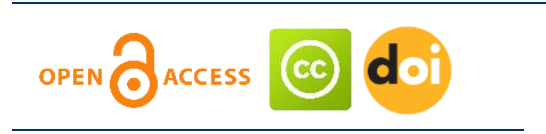

\section{Article history:}

Received: May 12, 2020

1st Revision: September 25,

2020

Accepted: November 07,

2020

\section{DOI:}

10.14254/jsdtl.2020.5-2.11
Abstract: This paper explores the decoupling trend between GDP and freight volumes in the ECOWAS states to develop short sea shipping model for the ECOWAS sub-region aimed at reducing the cost per transported unit within the sub-region. The research is based on cross-sectional data from ECOWAS countries spanning from 2000 to 2013 and sourced from the ECOWAS Commission and National Bureaus of Statistics of some member countries. The data were analysed using arc elasticity which is a transport demand modelling tool, to determine the level of variations among trade volumes in the ECOWAS sub-region. It was discovered that total freight volume improved proportionally with growth in GDP for most of the periods in the ECOWAS member countries. This is confirmed by the coefficients of elasticity close 1 or higher than 1 . In certain periods, however, the coefficient of elasticity of total freight volumes was found to be approximately zero, thus, indicating that considerable potential freights were lost. More stable values have the coefficients of general elasticity below 1 . In most of the ECOWAS countries, the coefficients of general elasticity are unstable, both negative and positive values have a range of values (from -43.709 to 52.364). Hence, freight traffic volume and GDP in the ECOWAS region is highly decoupled. This has raised a serious question as to the prudence of continued dominance of road transport mode for intra-regional freight movement in the ECOWAS sub-region. The result of the study revealed a strong correlation between GDP, the population of member states and the volume of freight in the ECOWAS member countries. The research also showed that the development of short sea shipping model in the sub-region would depend considerably on growth in GDP, improvement in the productivity of the population and increase in seaport corridors of the ECOWAS sub-region.

Corresponding author: Ejem A. Ejem

E-mail: ejemflagospel@yahoo.com 
Keywords: decoupling, economic activity, short-sea, shipping, ECOWAS.

\section{Introduction}

One of the enduring economic development frameworks of the $21^{\text {st }}$ Century is the phenomenon of Economic blocs at both regional and sub-regional levels. Since the 1960s, regional economic integration has been a goal pursued by most middle-income countries. Economic integration efforts have a long history in Africa. The large number of preferential trade agreements signed in the past five decades has led to a "spaghetti bowl" of intertwined and overlapping regional organizations. Every African country is a party to at least one regional economic agreement, and many are members of one or more. The combined gross domestic product (GDP) of ECOWAS member States is about USD142.9 billion growing at an average rate of around 4.8 per cent per annum. ECOWAS Commission, 2009). The economies of member countries of ECOWAS are diverse, although its major products include agricultural produce, crude oil and gas, fabric materials, mineral oil, etc. (United Nation Economic Commission for Africa report (2010).

Therefore, the free flow of trade among its member States is an important element in ECOWAS community development strategy and constitutes the main thrust of efforts and resources so far committed by the member States. However, notwithstanding the vigorous pursuit of improving intraregional trade within the ECOWAS Community which underlined the creation and operation of various institutional frameworks by governments of ECOWAS member States, improvement in trade (both quantitative and qualitative) among the Community member countries envisioned to catalyse economic growth and development of the sub-region has remained largely unrealised. Instead, intra-regional trade has continued to be weak, dysfunctional and generally underdeveloped. These features are true, a hallmark of the entire African region in terms of trade between countries of the continent. Although intra-Africa trade is not a panacea for development, it is quite important (Kimenyi, Routman, Westbury, Omiti, and Akande, (2012)). It can help the continent's industries become more competitive by creating economies of scale and weeding out producers that are less productive in the market place. Unfortunately, however, Africa's current internal trade is low- making up only about 10 per cent of its total trade (IMF Direction of Trade Statistics 2010). Most of its exports go to the world's advanced economies, and most of its imports come from those same advanced economies.

Compared with 69 per cent in Western Europe, 49 per cent in Asia and 40 per cent in North America, trade among African countries is abysmally low (European Commission (2011). It is particularly of concern that intra-Africa trade does not seem to be converging to these international levels; in recent years, it has been marked by only marginal improvements as shown in Table 1.

\begin{tabular}{|c|c|c|c|c|c|c|c|c|c|}
\hline Year & 2002 & 2003 & 2004 & 2005 & 2006 & 2007 & 2008 & 2009 & 2010 \\
\hline Per cent & 10 & 9 & 10 & 9 & 9 & 9 & 10 & 11 & 11 \\
\hline
\end{tabular}

Source: International Monetary Fund, Direction of Trade Statistics (2012)

Different factors have been adduced for the low and continuous underdevelopment of intraregional trade in Africa. Although the factors are many with varying degree of significance, one of the main factors that impinge on increasing intraregional trade level is infrastructure deficit (Kimenyi et al., 2012). Others important ones include regional integration, economic diversification, conflict and border issues. Infrastructure is and has always been a major issue for Africa, especially for Sub-Sahara countries. Like conflict, infrastructural deficiencies reduce economic growth and productivity and raise transportation costs. According to the United Nation Economic Commission for Africa report (2010), only about 30 per cent of African roads are paved and, as a consequence, "shipping a car from Japan to Abidjan costs $\$ 1,500$, while shipping that same vehicle from Addis Ababa to Abidjan would cost \$5,000" (UN Economic Commission for Africa, African Union and Africa Development Bank, 2010). This is largely explained by the absence of coastal shipping links between African countries. 
Africa's maritime ports have their problems; the same report estimates that the continent's port productivity is only 30 per cent of the international norm. Part of the reason for this underperformance is likely the unequal usage of the continent's ports; only six of its 90 total ports (three in Egypt and three in South Africa) handle 50 per cent of its trade. A related issue deals with costs; the port in Durban-SubSahara Africa's busiest port, charges more to dock a ship than any other major harbour in the world and double the world's average. Roads account for 80 to 90 per cent of all freight and passenger movement in Africa. Africa has a road density of only 16.8 kilometres, per 1,000 square kilometres, compared with 37 kilometres per 1,000 square kilometres in other low-income regions. Air travel within Africa continues to be more expensive per mile than intercontinental travel. Africa's inland waterways present an excellent opportunity to connect cities and countries. Seven rivers: the Nile, Congo, Niger, Senegal, Zambezi, Orange and Limpopo; while three Lakes; Victoria, Tanganyika and Malawi could be utilized to move goods across the region. However, due to political instability, social unrest, and the lack of highlevel government support for such projects, Africa's waterways remain the region's greatest untapped connectors (Kimenyi, Routman, Westbury, Omiti \& Akande, 2012).

ECD, (2006), shows a strong negative impact of transport cost on trade, especially for landlocked countries. Keeping distance constant, transport cost for landlocked countries are on average USD 2000 higher than for non- landlocked ones, an estimated 35\% difference. The lack of adequate transportation among states in West and Central Africa makes the cost of transporting people and cross-border trading quite prohibitive. These costs are a barrier to regional integration and free movement of persons and goods in the sub-region. Presently, the cost of shipping goods by sea along the coastline is prohibitive because, in many instances, goods between West African destinations are transhipped through Europe or South Africa because of the nonexistence of direct coastal sea links. It is, therefore, necessary and important to bridge the knowledge gap to provide the empirical basis for prioritizing transport infrastructural investments to effectively link the sub-region and facilitate trade among the countries. Such empirical evidence would also help in the formulation of regional transport development strategy and policy, as well as the business decisions of private investors.

The ECOWAS has become synonymous with the West African sub-region which lies between $13.5317^{\circ} \mathrm{N}, 2.4604^{\circ} \mathrm{W}$ and it is used interchangeably to refer to the fifteen countries that made up West Africa. West Africa (ECOWAS) is bordered in the north by the Sahara Desert. To the west and south, the region is bordered by the Atlantic Ocean; and to the east, by the mountains of Cameroon. West Africa has varied vegetation zones of desert, semi-desert, savannah and forest.

\section{Figure 1: Map of the ECOWAS Sub-region}

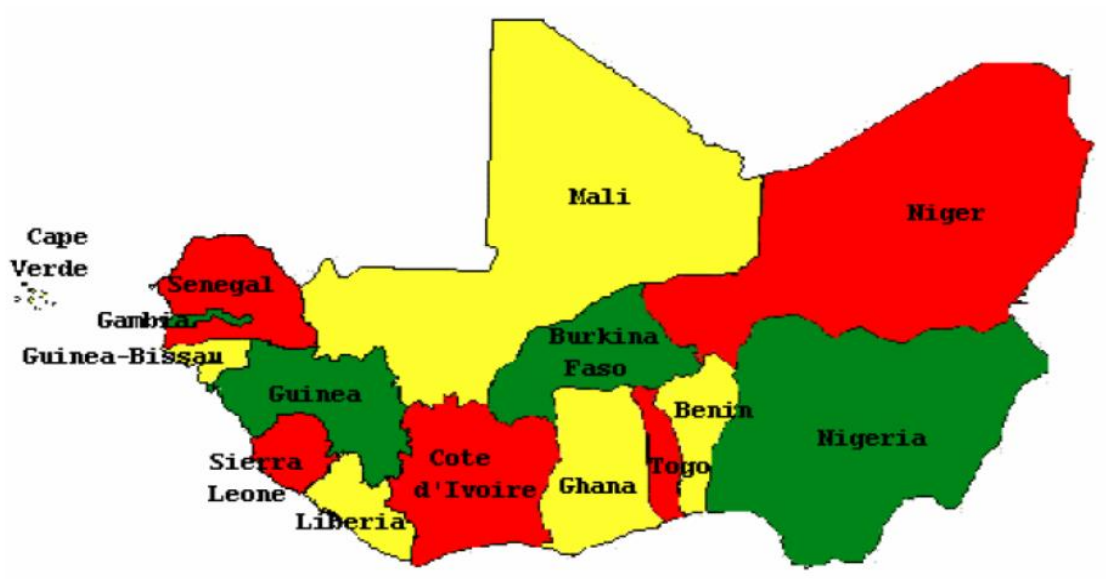

\section{Literature review}

The economic development of a country is, in a broad sense, mainly driven by its level of investment, trade and consumption, and it is a phenomenon that not only diverges on the country level but also the regional level like ECOWAS. As a means of enabling trade, freight transport is assumed to be a key factor of the economic level achieved by ECOWAS. The relationship between freight transport 
and economic activity has been the object of several studies (Meersman \& Van de Voorde, 2003; Rommerskirchen, 2003). It is fairly established that historically, the growth of freight transport has accompanied economic growth. Given this close relationship, two main questions arrive. The first relates to the decoupling of freight transport and economic growth. This subject has recently been occupying much of the transport literature, mainly since the European Commission's 2001 White Paper on Transport (Commission, 2001) has referred to decoupling as the main goal for European Transport Policy, due to the negative impact of transport in the environment. Decoupling is defined by Banister (Banister and Berechman, 2001) as "a decrease in transport intensity of GDP that will allow the volume of transport to increase at a slower rate than the economy at large". McKinnon (2007) also argues that in the UK between 1997 and 2004 a decoupling trend was observed. The study proposes possible reasons for this trend, and points to the growth of foreign road haulage operators, the reduction of road transport in the modal split and the increases in road freight rates as the most significant ones. Still in the context of time series, but looking more in-depth into the type of relationship between GDP and transport, Tapio (2005) distinguishes between three general types of relations: the GDP growth and the growth of transport can be coupled, decoupled or negatively decoupled. This author also found that in the 1990s there were differences between countries within the EU in the degree of decoupling. While in the UK, Germany, Luxembourg, Austria, Finland, the Netherlands and Sweden a weak decoupling could be observed, countries like Ireland, Denmark, France and Belgium showed expansive coupling (Tapio, 2005). In what concerns studies using cross-section data, Benathan, Fraser and Thompson (1992) investigate the domestic (non-transit) demand for freight transport with correlating ton-kilometres (ton-km) with total GDP and country area for 33 countries. The authors contend that GDP and country area is the long-run determinants of domestic freight transport, measured in ton-km.

It is quite obvious, that there is a kind of correlation between economic growth (measured by GDP) and the demand for freight transport. The production and the distribution of goods generate demand for freight transportation. Demand for products again is influenced by the general economic situation. The energy sector serves as a positive example for decoupling. After the oil crises in the seventies and eighties, decoupling of energy consumption from economic growth was attained in several countries (e.g. in Germany). Decoupling was caused by improved energy efficiency, by the application of advanced technologies and by behavioural changes (McKinnon, 2006). Decoupling of growth of freight transport performance from the growth of GDP has to be seen differentiated: The analysis of transport elasticities, transport intensities and the correlation analysis has shown that certain decoupling tendencies are visible in France, the Netherlands and Great Britain. For these countries, transport elasticities are predominantly below 1.0. The analyses show weaker growth in transport performance than of GDP. However, the transport elasticities for the most recent time are except for the Netherlands - clearly beyond 1.0. Furthermore, the transport intensities show an increase in 1996 compared to 1990 (although again the Netherlands is an exception). The results demonstrate that decoupling has not taken place in Germany, Belgium, Italy and Spain; and although certain decoupling tendencies can be recognised in France and Great Britain, decoupling cannot be considered to have been attained. This is because transport intensities and transport elasticities have increased during the most recent period 1990-1996. However, according to the analyses applied, clear decoupling tendencies can be recognised in the Netherlands. The analyses clearly show that decoupling of growth of road transport performance from economic growth has not taken place. Growth rates of road transport performance have markedly exceeded growth rates of GDP. Among the seven considered countries France, Great Britain and the Netherlands are those countries, which are closest to the attainment of decoupling road freight transport performance growth from economic growth (McKinnon, 2006).

Although freight transport by all modes is closely related to GDP, airfreight transport is more sensitive to GDP than other modes. Since 1970, air cargo traffic (measured in revenue ton-km) has expanded by about $7.1 \%$ annually (i.e., more than 2.4 times faster than the rate of GDP growth), leading to an almost eightfold increase in total traffic volumes. The impact of economic downturns or political crises on airfreight development is more severe than on freight transport by other modes. Total world airfreight growth and world GDP growth show a clear correlation. The peaks and troughs in freight traffic and GDP growth often coincide. During periods of strong economic growth, airfreight growth has topped $10 \%$ per year. In economic downturns, however, airfreight has shown negative growth. McKinnon (2006), which assesses the evidence for decoupling between road freight demand and 
economic growth in the UK and reviews some of the most important studies, which estimate the price and income elasticities of road freight demand, measured in tonne-kilometres. In general terms, decoupling takes place when the ratio between the per cent growth of a transport-related variable, for example, passenger traffic or freight demand as defined in this study, and the per cent growth of an economic variable is less than unity (Tapio, 2005). In most instances, including McKinnon (2006) and Tapio (2005), the analysis of decoupling is implemented by assessing percentage changes in the variables rather than elasticities from econometric models. Tapio (2005) distinguished between weak, strong and recessive decoupling. In weak decoupling, the value of the ratio mentioned above falls to between 0 and 0.8 . Strong decoupling occurs when the ratio is smaller than zero while the economy is growing. Finally, recessive decoupling takes place when the ratio is higher than 1.2 and the economy is shrinking. In McKinnon (2007) the terms decoupling refers more precisely to the ratio between per cent changes of road freight demand, measured in tonne-km, and the GDP measured in real terms. The author notes that between 1997 and 2004, GDP in the UK increased by one-fifth, while road freight remained relatively stable. The ratio mentioned above was about 0.38 . The author concludes that the long-awaited decoupling of economic and freight transport growth has begun. From the literature above, there is a shred of strong evidence that the decoupling trend has not been established at ECOWAS sub-region. Hence this gap in the literature has provided an impetus to further explore the decoupling trend between GDP and freight volumes in the ECOWAS states.

\section{Methodology}

Data used in this study was sourced mainly from secondary sources. They include data provided by the national bureau of statistics of key member countries of ECOWAS (Nigeria, Ghana, Ivory Coast, Senegal, Togo, Mali and Niger). Data from these national institutions was complemented by trade and economic information provided by the ECOWAS Trade Commission at the ECOWAS Secretariat. The researcher undertook visits to these institutions in the respective countries and the staff of Nigeria's High Commissions in the countries facilitated the researcher's access to the institutions, as well as relevant departments and officers. Several visits were made to the ECOWAS Trade Commission at Abuja because the researcher relied exclusively on the Commission for trade and economic statistics for the countries not visited. The researcher also relied on the Commission for the translation of data from French-speaking ECOWAS member countries to English.

Freight movement within the sub-region was examined and a simple percentage was used to determine the change of freight volume between the periods 2000 and 2013. However, the maritime trade volume in the ECOWAS sub-region has been so small and this requires urgent boost through the development of short-sea shipping infrastructure. Analysis of freight traffic volume forecast was based on the arc elasticity coefficient method. This study applied the elasticity coefficient to determine freight volume firstly. According to GPD data of different regions from 2001 to 2014 and the data of freight traffic volume, elasticity coefficient of freight volume in different regions was calculated. Further, the elasticity coefficient has been used to forecast the behaviour of freight traffic volume from 2011 to 2015 in different ECOWAS countries. This is a technique for decoupling the link between freight volume and the GDP of respective countries in the ECOWAS bloc.

The transport elasticity coefficient is defined as a numerical measure of the relative response of freight traffic volume to changes in GDP, which can be expressed as follows: Transportation elasticity coefficient $=$ Rate of change of freight traffic volume / Rate of change of GDP. In this research, freight traffic volume and GDP in different countries are used to calculate transportation elasticity coefficient. Comparing the growth of GDP to the growth of changes of demand for freight transport, we could calculate the freight transport elasticity employing the following arc elasticity formula:

$$
\eta_{a, b}^{Y}=\frac{\Delta Y_{a, b}}{\frac{\left(Y_{a}+Y_{b}\right)}{2}} \div \frac{\Delta G D P_{a, b}}{\frac{\left(G D P_{a}+G D P_{b}\right)}{2}},
$$

Where

$\eta$ - Freight transport elasticity,

$Y$ - transport demand indicator (freight transport volume) in million $\mathrm{t}$,

$G D P$ - the Gross Domestic Product at current prices in million US Dollars, 
$a, b$ - time $\eta$ refers to (time between year $a$ and year $b$ ).

\section{Results}

\subsection{Analysis of freight volumes within ECOWAS}

Continuous changes in the international market of freight transport require not only the modernization of the current transport infrastructure but also the introduction of modern technologies for shipping management built around analytical frameworks. In the ECOWAS sub-region, these changes are mainly driven by increased competition among modes, as well as the dynamic interplay of factors that affect freight movements such as fiscal regime, trade policy, non-tariff barriers, colonial influence and political stability of the member countries. The countries of ECOWAS sub-region determine the level of development of the maritime activities taking into account changes in basic economic indicators such as GDP, exchange rate, population, etc. The influence of these indices on maritime freight transport industry is defined by methods of statistical analysis. The several ECOWAS States have similar challenges and prospects in the development of the maritime industry. The following general conditions of development of freight transport are characteristic to the ECOWAS sub-region: similarity of geographical location; existing transport modes; economic structural imbalance; low level of trade; policy instability and weak regulatory environment.

The consideration and comparison of the basic indices of freight are conditioned by the level of economic development and by policymakers in the transport sector of the ECOWAS sub-region. A realistic analysis of freight transport indices of the ECOWAS member states must be conducted simultaneously within the period ECOWAS came into existence, especially the period it provided key trade facilitation mechanisms. This is because it was only the coming into existence of ECOWAS that brought about structured effort at the multilateral level to promote trade among the countries of the sub-region. The distribution of the freight volumes across the countries in Table 2 presumes a great future for short sea shipping in the ECOWAS sub-region with navigable sea connectivity.

\begin{tabular}{|c|c|c|c|c|c|c|c|c|c|c|c|c|c|c|c|}
\hline Country & 2000 & 2001 & 2002 & 2003 & 2004 & 2005 & 2006 & 2007 & 2008 & 2009 & 2010 & 2011 & 2012 & 2013 & Total \\
\hline Benin & 120 & 178 & 224 & 268 & 286 & 298.4 & 676.8 & 636.1 & 551.5 & 755.7 & 543.2 & 454.3 & 453.3 & 546.4 & 5991.7 \\
\hline Burkina Faso & 159 & 192 & 194 & 624 & 776 & 394.4 & 511.2 & 594.9 & 666.3 & 596.9 & 697.2 & 764.6 & 896.3 & $1,066.6$ & 8133.4 \\
\hline Cape Verde & 3 & 7 & 13 & 40 & 39 & 47.1 & 79.2 & 52.3 & 17.0 & 17.7 & 11.6 & 14.0 & 10.7 & 13.7 & 365.3 \\
\hline Cote d'Ivoire & 1,604 & 1,426 & 1,655 & 1,523 & 2,481 & $3,303.6$ & $3,660.8$ & $3,786.3$ & $5,067.4$ & $4,131.8$ & $4,755.7$ & $4,083.9$ & $5,557.3$ & $7,372.6$ & 50408.4 \\
\hline Gambia & 34 & 14 & 14 & 13 & 37 & 40.8 & 36.7 & 34.4 & 45.0 & 55.2 & 101.8 & 173.0 & 225.5 & 196.0 & 1020.4 \\
\hline Ghana & 539 & 541 & 646 & 841 & 610 & 947.1 & $3,267.8$ & $1,473.7$ & $1,525.7$ & $1,124.4$ & $1,386.1$ & $7,762.5$ & $2,420.2$ & $1,769.2$ & 24853.7 \\
\hline Guinea & 75 & 102 & 117 & 125 & 193 & 293.5 & 209.2 & 40.0 & 147.4 & 97.0 & 234.8 & 245.8 & 265.5 & 54.7 & 2199.9 \\
\hline $\begin{array}{l}\text { Guinea } \\
\text { Bissau }\end{array}$ & 7 & 9 & 12 & 12 & 43 & 43.6 & 42.1 & 44.6 & 30.6 & 26.6 & 20.9 & 23.7 & 24.9 & 14.5 & 354.5 \\
\hline Liberia & 3 & 3 & 0 & 2 & 4 & 6.8 & 8.5 & 6.7 & 76.1 & 7.4 & 8.1 & 7.6 & 18.9 & 31.2 & 183.3 \\
\hline Mali & 354 & 424 & 418 & 535 & 776 & 610.2 & 789.8 & $1,238.6$ & $1,567.5$ & $1,070.5$ & $1,316.9$ & $1,788.5$ & $1,915.5$ & $1,572.8$ & $\begin{array}{c}14377 . \\
3\end{array}$ \\
\hline Niger & 196 & 187 & 201 & 241 & 319 & 285.6 & 263.5 & 308.2 & 423.6 & 393.0 & 443.1 & 452.0 & 668.4 & 764.8 & 5146.2 \\
\hline Nigeria & 1,516 & 1,15 & 1,278 & 1,462 & 1,740 & $2,794.9$ & $3,963.6$ & $3,075.8$ & $6,797.3$ & $2,221.7$ & $2,226.8$ & $5,158.4$ & $5,671.6$ & $\begin{array}{c}10,451 \\
0\end{array}$ & 49507.1 \\
\hline Senegal & 439 & 498 & 599 & 856 & 1,038 & $1,102.9$ & 786.0 & $1,273.5$ & $1,453.5$ & $1,281.7$ & $1,436.9$ & $1,574.2$ & $1,802.2$ & $1,813.1$ & 15954 \\
\hline Sierra Leone & 37 & 78 & 56 & 65 & 57 & 75.9 & 590.6 & 334.5 & 333.6 & 336.1 & 255.0 & 287.6 & 388.8 & 654.9 & 3550 \\
\hline Togo & 95 & 138 & 149 & 246 & 293 & 218.4 & 250.3 & 295.9 & 481.9 & 522.7 & 246.3 & 651.4 & 721.0 & 900.3 & 5209.2 \\
\hline Total & 5181 & 4947 & 5576 & 6853 & 8692 & 10463.2 & 15136.1 & 13195.5 & 19184.4 & 12638.4 & $\begin{array}{c}13684 . \\
4 \\
\end{array}$ & $\begin{array}{c}23441 . \\
5 \\
\end{array}$ & $\begin{array}{c}21040 . \\
1 \\
\end{array}$ & 27221.8 & \\
\hline
\end{tabular}

Source: Compiled from ECOWAS Commission Freight Volume statistics

Let us consider the statistical data taking into consideration the total volumes of freight transport of three countries (Nigeria, Benin and Togo) with interconnected sea route for the period 2000 to 2013. The freight transport of Nigeria is (general volume of 49,508 million tonnes) by 12.1 times exceeds the volume of freight of Benin Republic (general volume of 5,992 million tonnes), which in turn is by 10.5 times exceeds the volume of freight of Togo (general volume being 5,210 million tonnes). 
Table 3: Change in freight volume in ECOWAS states

Percentage Change of Freight Volume between

Country the periods 2000 and 2013

\begin{tabular}{lc}
\hline Benin & 453.9 \\
Burkina Faso & 670.7 \\
Cape Verde & 501.8 \\
Cote d'Ivoire & 459.6 \\
The Gambia & 572.7 \\
Ghana & 328.4 \\
Guinea & 73.0 \\
Guinea Bissau & 207.0 \\
Liberia & 1038.6 \\
Mali & 444.2 \\
Niger & 390.1 \\
Nigeria & 689.3 \\
Senegal & 413.2 \\
Sierra Leone & 1749.6 \\
Togo & 946.4 \\
\hline Source: Computed from ECOWAS Commission Freight Volume statistics
\end{tabular}

Source: Computed from ECOWAS Commission Freight Volume statistics

For the analyzed period (Nigeria, Benin and Togo) the total volumes of freight transportation were increased geometrically by $689.3 \%, 453.9 \%$ and $946.4 \%$ respectively, but in Cape Verde, Guinea and Guinea Bissau the total volume of freight went up astronomically to $501.8 \%, 73.0 \%$ and $207.0 \%$ respectively. See Table 3 for the other ECOWAS states. Hence it is imperative to note that across the subregion, freight movement has been on the increase thereby requiring modern technologies offered by short sea shipping to expedite economic efficiency of trade within the sub-region. However, the maritime trade volume in the ECOWAS sub-region has been so small (see Table 4 and Fig. 2) and this requires urgent boost through the development of short-sea shipping infrastructure.

\section{Table 4: Modal Share of Freight Volumes in ECOWAS Nations from 2000-2013}

\begin{tabular}{|c|c|c|c|c|c|}
\hline Country & $\begin{array}{c}\text { Average } \\
\text { Annual Road } \\
\text { transport trade } \\
\text { volume (in } \\
\text { million tonnes) }\end{array}$ & $\begin{array}{l}\text { Average Annual } \\
\text { Maritime trade } \\
\text { volume (in } \\
\text { million tonnes) }\end{array}$ & $\begin{array}{l}\text { Combined } \\
\text { Average Annual } \\
\text { trade volume (in } \\
\text { million tonnes) }\end{array}$ & $\begin{array}{c}\text { \% Road } \\
\text { Transport } \\
\text { Share }\end{array}$ & $\begin{array}{c}\text { \% Maritime } \\
\text { Share }\end{array}$ \\
\hline Benin & 424.61 & 3.28 & 427.89 & 99 & 1 \\
\hline Burkina Faso & 580.99 & 0.00 & 580.99 & 100 & 0 \\
\hline Cape Verde & 25.14 & 0.89 & 26.03 & 97 & 3 \\
\hline Cote d'Ivoire & 3598.31 & 2.14 & 3600.46 & 99 & 1 \\
\hline The Gambia & 71.99 & 0.87 & 72.87 & 99 & 1 \\
\hline Ghana & 1762.03 & 11.01 & 1773.04 & 99 & 1 \\
\hline Guinea & 154.91 & 1.78 & 156.69 & 99 & 1 \\
\hline Guinea Bissau & 25.10 & 0.21 & 25.31 & 99 & 1 \\
\hline Liberia & 12.46 & 0.56 & 13.02 & 96 & 4 \\
\hline Mali & 1027.00 & 0.00 & 1027.00 & 100 & 0 \\
\hline Niger & 367.59 & 0.00 & 367.59 & 100 & 0 \\
\hline Nigeria & 3507.82 & 20.93 & 3528.75 & 99 & 1 \\
\hline Senegal & 1129.96 & 8.15 & 1138.11 & 99 & 1 \\
\hline Sierra Leone & 253.52 & 0.07 & 253.58 & 100 & 0 \\
\hline Togo & 369.63 & 2.26 & 371.89 & 99 & 1 \\
\hline
\end{tabular}

Source: Computed from ECOWAS Commission Freight Volume statistics

Seaports play a major role as logistics centres and require efficient hinterland connections. Their development is vital to handle increased volumes of freight both by SSS within the ECOWAS region and with the rest of the world. Inland waterways, where the unused potential exists, have to play an increasing role in particular in moving goods to the hinterland and in linking the ECOWAS coastal areas. In terms of freight volume in the ECOWAS sub-region, fifteen main markets can be distinguished according to the nations. Each market has its dynamics: the routing of different types of freight through ECOWAS traffic corridors is guided by complex interactions between a large set of factors and actors. 
Figure 2: Modal Share of Freight Volumes in ECOWAS Nations from 2000-2013

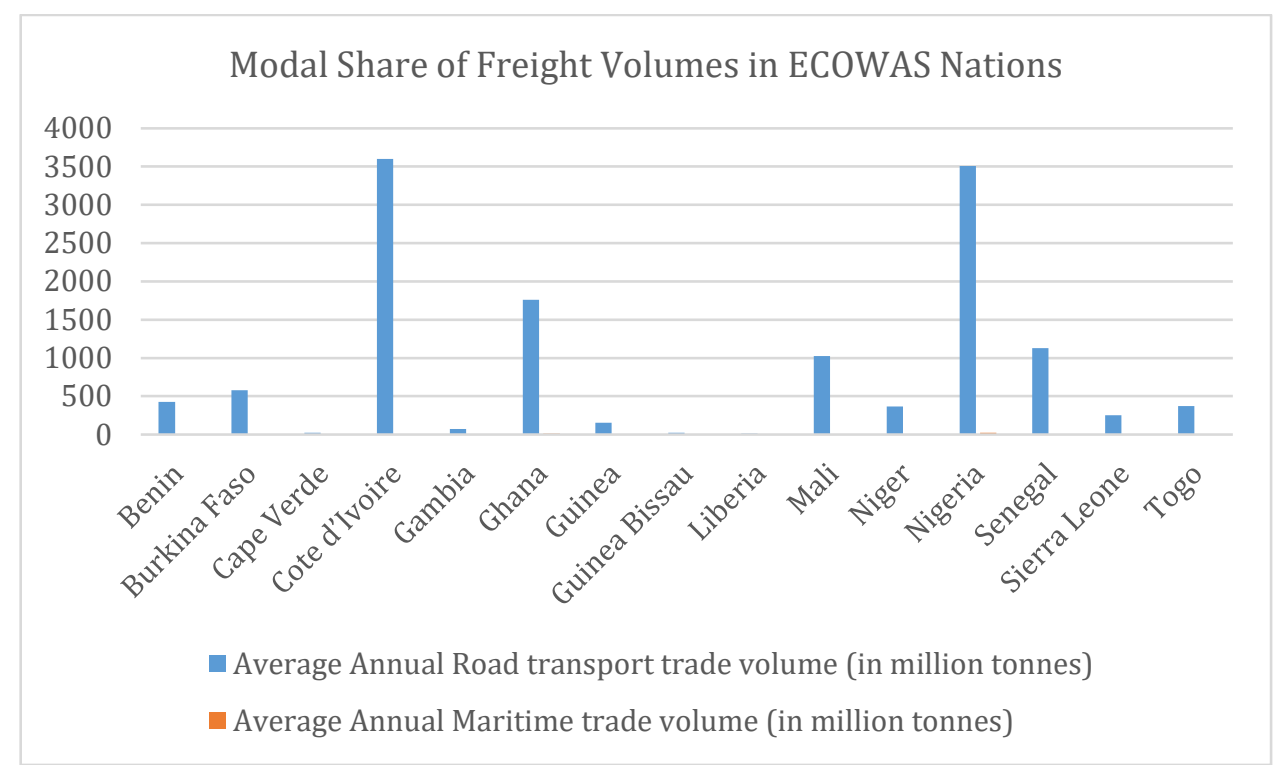

However, all corridors and types of trade have two underlying common factors that influence the routing to the nations: the connectivity of the nations through their seaport corridors and the level of performance of the trade among the states. Some of the countries with zero values in maritime trade volumes such as Burkina Faso, Mali and Niger are land-locked hence, the short- sea-shipping option is ruled out by nature limited. The other countries have a small volume of maritime trade within them, Liberia had the highest volume of maritime trade with $0.04 \%$ of her overall trade volume, and this is closely followed by Cape Verde with approximately $0.03 \%$ of the maritime share. The other nations have maritime trade volume ranging from $0.0001 \%$ to $0.009 \%$. These figures are grossly insignificant considering great economies of scale that the maritime mode offers. This is a wide gap considering that short sea transport represents approximately $60 \%$ of the traffic of EU ports (Pastori, 2015). While for natural limitation reasons a modal switch to short sea shipping is viewed as beneficial, it is possible for economic and political reasons that some countries have witnessed considerable switch of freight away from the sea. Thus, over the period 2000 to 2013, in the 15 ECOWAS Member States, and particularly in Nigeria and Cote d'Ivoire, the road has a dominant modal share of the annual average of 3507.82 and 3598.31 million tonnes respectively. However, in many other Member States, there has been a considerable modal switch to the road with over $99 \%$ of freight volumes moved by road except Cape Verde and Liberia which recorded $96.6 \%$ and $95.7 \%$ respectively.

\subsection{Analysis of freight transport elasticity of ECOWAS states}

In Table 5 the coefficients of elasticity are reflected for the whole analysed period (2000-2013) and the six years periodic intervals. When the coefficients of import freight volumes general elasticity of the ECOWAS countries at certain periods is less than 1, it shows that for the period 2000 to 2013, the freight transport industry of these countries did not use the general potential of development, as the economy of the countries had more considerable growth compared to the growth of the import freight transport volume. More stable values have the coefficients of general elasticity below 1 . In most of the ECOWAS countries, the coefficients of general elasticity are unstable, both negative and positive values have a range of values (from -43.709 to 52.364 ). 


\begin{tabular}{|c|c|c|c|c|c|c|c|c|c|c|}
\hline Country & $\begin{array}{c}2000- \\
2013\end{array}$ & $\begin{array}{c}2001- \\
2005\end{array}$ & $\begin{array}{l}2002- \\
2006\end{array}$ & $\begin{array}{c}2003- \\
2007\end{array}$ & $\begin{array}{c}2004- \\
2008\end{array}$ & $\begin{array}{l}2005- \\
2009\end{array}$ & $\begin{array}{c}2006- \\
2010\end{array}$ & $\begin{array}{c}2007- \\
2011\end{array}$ & $\begin{array}{c}2008- \\
2012\end{array}$ & $\begin{array}{c}2009- \\
2013\end{array}$ \\
\hline Benin & 1.07 & 1.23 & 0.59 & 2.14 & 1.95 & 1.24 & -1.96 & -1.10 & -0.15 & -0.95 \\
\hline Burkina Faso & 1.17 & 1.71 & 1.05 & 1.38 & 0.41 & 0.35 & 1.20 & 1.31 & 1.33 & 1.68 \\
\hline Cape Verde & 0.72 & 3.27 & 3.02 & 2.91 & 0.25 & -1.57 & -2.25 & -2.20 & -0.73 & -2.07 \\
\hline Cote d'Ivoire & 1.34 & 0.88 & 1.96 & 3.25 & 3.17 & 2.33 & 0.69 & -0.01 & 0.68 & 2.67 \\
\hline Gambia & 3.68 & -0.92 & -5.89 & 12.52 & 2.23 & 0.24 & 1.83 & 4.80 & 52.36 & 3.05 \\
\hline Ghana & -0.01 & 0.17 & 0.54 & -0.74 & -0.39 & 0.87 & 2.47 & 1.97 & -1.84 & -0.17 \\
\hline Guinea & -8.40 & 4.21 & -20.97 & -1.84 & 3.42 & 5.26 & -5.59 & -18.87 & -43.71 & -5.44 \\
\hline Guinea Bissau & 0.63 & 4.97 & 2.96 & 2.29 & 2.33 & -0.77 & -1.56 & -1.49 & -0.67 & -1.08 \\
\hline Liberia & 1.73 & 1.48 & 15.29 & 13.73 & 2.44 & 4.54 & -0.98 & -0.46 & -2.83 & 3.40 \\
\hline Mali & 1.02 & 1.33 & 0.69 & 1.09 & 1.63 & 1.17 & 1.12 & 0.70 & 0.98 & 1.51 \\
\hline Niger & 0.83 & 1.44 & 0.94 & 0.74 & 0.43 & -0.14 & 0.65 & 1.08 & 1.33 & 1.09 \\
\hline Nigeria & 1.50 & 2.81 & 1.18 & 1.06 & 0.77 & 1.20 & -0.90 & -0.01 & -10.02 & 4.52 \\
\hline Senegal & 0.76 & 1.37 & 1.24 & 0.05 & 0.75 & 0.57 & 0.87 & -0.33 & 0.09 & 1.25 \\
\hline Sierra Leone & 1.75 & 1.14 & -0.08 & 7.38 & 4.41 & 2.89 & -4.01 & -2.33 & 2.85 & 2.35 \\
\hline Togo & 1.17 & 1.27 & 1.25 & 1.30 & 0.68 & 1.09 & 1.24 & 1.75 & 0.59 & 2.08 \\
\hline
\end{tabular}

Source: Computed from ECOWAS Commission Freight Volume statistics

Examining the coefficients of elasticity of export from 2000 through 2013 in Table 5 we could conclude that the volumes of export cargo considerably fell behind the rates of growth of GDP. The reduction of the coefficient of elasticity of import for 2000-2013 in the ECOWAS countries compared with the increase of the volumes of freight at the same period demonstrates the growth of GDP and lagging of the rate of development of the means of transport employed in the economic trade bloc.

\begin{tabular}{|c|c|c|c|c|c|c|c|c|c|c|}
\hline Country & $\begin{array}{l}2000- \\
2013\end{array}$ & $\begin{array}{l}2001- \\
2005\end{array}$ & $\begin{array}{l}2002- \\
2006 \\
\end{array}$ & $\begin{array}{l}2003- \\
2007 \\
\end{array}$ & $\begin{array}{l}2004- \\
2008 \\
\end{array}$ & $\begin{array}{l}2005- \\
2009 \\
\end{array}$ & $\begin{array}{l}2006- \\
2010\end{array}$ & $\begin{array}{l}2007- \\
2011 \\
\end{array}$ & $\begin{array}{l}2008- \\
2012 \\
\end{array}$ & $\begin{array}{l}2009- \\
2013\end{array}$ \\
\hline Benin & 1.36 & 2.49 & 1.95 & 1.23 & 1.29 & 1.57 & 2.61 & -1.88 & -3.99 & -2.27 \\
\hline Burkina Faso & 1.07 & 2.47 & 1.02 & 1.64 & -0.97 & -1.80 & -0.06 & -0.86 & -0.26 & 1.57 \\
\hline Cape Verde & 1.40 & 0.70 & -3.13 & 0.20 & 4.61 & 2.83 & -1.11 & -0.29 & -2.94 & 1.72 \\
\hline Cote d'Ivoire & 1.33 & 1.06 & 1.37 & 1.14 & 2.27 & 1.51 & 0.85 & 0.61 & 0.47 & 2.02 \\
\hline Gambia & 5.17 & 4.99 & -8.66 & 20.00 & 4.17 & 2.72 & 4.59 & 9.05 & 100.15 & 8.49 \\
\hline Ghana & 1.04 & 0.42 & 0.44 & 1.67 & 1.30 & 0.65 & -2.87 & 3.15 & 3.84 & 1.27 \\
\hline Guinea & 14.95 & 4.20 & -35.13 & -0.87 & 6.24 & -7.96 & 10.19 & -35.66 & -98.06 & -5.24 \\
\hline Guinea Bissau & 1.83 & 6.90 & 4.06 & -0.61 & 0.67 & 0.63 & 1.39 & 4.00 & 2.82 & -4.47 \\
\hline Liberia & 2.14 & 41.98 & 6.86 & 8.24 & 1.60 & 4.28 & 2.11 & 1.43 & -1.28 & -0.37 \\
\hline Mali & 0.96 & 0.62 & 0.35 & 0.22 & 0.69 & 1.58 & 2.24 & 2.70 & 0.89 & 1.48 \\
\hline Niger & 0.97 & -0.06 & 0.21 & -0.06 & 0.33 & 1.33 & 2.24 & 2.41 & 1.65 & 2.28 \\
\hline Nigeria & 0.96 & -0.02 & 1.24 & 1.14 & 0.77 & 1.50 & -2.05 & 3.29 & -0.44 & 2.22 \\
\hline Senegal & 1.37 & 2.04 & 1.65 & 1.17 & 1.00 & 0.96 & 1.93 & 1.68 & 1.82 & 0.95 \\
\hline Sierra Leone & 1.84 & -5.11 & -2.31 & 3.06 & 4.31 & 4.91 & 5.90 & 15.96 & -9.74 & -1.87 \\
\hline Togo & 1.93 & 3.33 & 1.65 & 1.11 & 0.27 & 1.38 & -1.22 & 4.95 & 3.56 & 2.49 \\
\hline
\end{tabular}

Source: Computed from ECOWAS Commission Freight Volume statistics 


\begin{tabular}{lcccccccccc}
\multicolumn{1}{l}{ Table 7: Total freight transport elasticity for ECOWAS Sub-Region } \\
\hline Country & $\mathbf{2 0 0 0 -}$ & $\mathbf{2 0 0 1 -}$ & $\mathbf{2 0 0 2}-$ & $\mathbf{2 0 0 3 -}$ & $\mathbf{2 0 0 4 -}$ & $\mathbf{2 0 0 5}-$ & $\mathbf{2 0 0 6}-$ & $\mathbf{2 0 0 7 -}$ & $\mathbf{2 0 0 8 -}$ & $\mathbf{2 0 0 9 -}$ \\
& $\mathbf{2 0 1 3}$ & $\mathbf{2 0 0 5}$ & $\mathbf{2 0 0 6}$ & $\mathbf{2 0 0 7}$ & $\mathbf{2 0 0 8}$ & $\mathbf{2 0 0 9}$ & $\mathbf{2 0 1 0}$ & $\mathbf{2 0 1 1}$ & $\mathbf{2 0 1 2}$ & $\mathbf{2 0 1 3}$ \\
\hline Benin & 1.13 & 1.52 & 0.93 & 1.99 & 1.82 & 1.34 & -0.67 & -1.23 & -1.12 & -1.29 \\
Burkina Faso & 1.15 & 2.00 & 1.04 & 1.44 & -0.09 & -0.33 & 0.94 & 0.83 & 1.06 & 1.66 \\
Cape Verde & 0.97 & 3.25 & 2.83 & 2.76 & 0.63 & -1.19 & -2.20 & -1.78 & -1.21 & -0.93 \\
Cote d'Ivoire & 1.34 & 0.98 & 1.62 & 1.99 & 2.66 & 1.90 & 0.77 & 0.33 & 0.57 & 2.29 \\
Gambia & 4.35 & -0.20 & -6.05 & 13.17 & 2.38 & 0.33 & 2.64 & 6.55 & 70.53 & 5.18 \\
Ghana & 0.67 & 0.23 & 0.52 & 1.25 & 0.52 & 0.82 & -1.80 & 2.95 & 1.25 & 0.85 \\
Guinea & -3.50 & 4.21 & -23.30 & -1.76 & 4.71 & 1.39 & 0.71 & -29.58 & -79.49 & -5.36 \\
Guinea Bissau & 0.64 & 4.99 & 2.98 & 2.26 & 2.33 & -0.75 & -1.53 & -1.33 & -0.51 & -1.37 \\
Liberia & 1.77 & 4.61 & 13.79 & 12.66 & 2.17 & 4.51 & -0.12 & 0.28 & -2.66 & 2.75 \\
Mali & 1.01 & 1.23 & 0.62 & 0.97 & 1.51 & 1.23 & 1.28 & 1.02 & 0.97 & 1.50 \\
Niger & 0.91 & 0.88 & 0.69 & 0.49 & 0.40 & 0.47 & 1.25 & 1.58 & 1.50 & 1.71 \\
Nigeria & 1.16 & 0.32 & 1.22 & 1.13 & 0.77 & 1.46 & -1.97 & 2.68 & -1.26 & 3.03 \\
Senegal & 1.04 & 1.57 & 1.35 & 0.51 & 0.84 & 0.71 & 1.45 & 0.58 & 0.82 & 1.09 \\
Sierra Leone & 1.76 & 1.07 & -0.13 & 7.36 & 4.41 & 3.48 & -3.91 & -1.49 & 0.80 & 1.96 \\
Togo & 1.73 & 2.47 & 1.49 & 1.19 & 0.42 & 1.29 & -0.07 & 4.04 & 2.77 & 2.39 \\
\hline
\end{tabular}

Source: Computed from ECOWAS Freight Volume statistics

The total freight volume improved proportionally with the growth in GDP in most of the periods in ECOWAS countries. This is confirmed by the coefficients of elasticity being near or higher than 1 (See Table 7). The coefficient of elasticity of total freight volumes for certain periods being less than zero proves a considerable loss of the total freight transport in transits. Using the coefficients of elasticity we could infer that ECOWAS countries have huge potential for short sea shipping in freight transport. This is based on the fact that the sensitivity of the freight volumes to GPD growth among ECOWAS member countries showed elastic nature of their relationship in almost the countries within the study period; 2000-2013. Hence, freight traffic volume and GDP in the ECOWAS region is highly decoupled.

\section{Conclusion}

There has been a steady growth in freight traffic across the ECOWAS sub-region thereby requiring modern technologies and advantages offered by short sea shipping to drive trade efficiency and economic development in the sub-region. Moreover, the freight share of maritime mode in ECOWAS total trade volume has been insignificant and thus requires to be boosted through the development of short-sea shipping infrastructure and capacity in the sub-region. Liberia had the highest volume of maritime trade with $0.04 \%$ of her overall trade volume, and this is closely followed by Cape Verde with approximately $0.03 \%$ of the maritime share. The other nations have maritime trade volume ranging from $0.0001 \%$ to $0.009 \%$. These figures are grossly insignificant considering great economies of scale that the maritime mode offers.

The coefficients of elasticity are determined for the entire period under analysis (2000-2013) and for the six years' time intervals. The coefficients of import and export freight volumes general elasticity of the ECOWAS countries at certain period being less than 1, shows that for the period from 2000 to 2013 the freight transport industry of these countries did not use the full growth potential as the economics of the countries had more considerable growth than compared to the growth of the freight volume. More stable values have the coefficients of general elasticity less than 1 in 2006-2010. it has to be recognized that ECOWAS sub-region should vigorously pursue the development of short-sea shipping because it has been proven to be a transport mode that could offer a realistic prospect of substantial modal shift from the congested roads and artificial barriers to trade occasioned by roadblocks and checking points mounted by agencies of the various countries to reduce environmental damage and other negative externalities. 


\section{Citation information}

Elem, T. R., Ogwude, I. C., Ibe, C. C., Nnadi, K. U., \& Ejem, E. A. (2020). Decoupling of economic activity and freight transport volume: An evidence for short sea shipping future in the ECOWAS subregion. Journal of Sustainable Development of Transport and Logistics, 5(2), 124-134. doi:10.14254/jsdtl.2020.5-2.11.

\section{References}

Banister, D., \& Berechman, Y. (2001). Transport investment and the promotion of economic growth. Journal of Transport Geography, 9, 209-218.

Bennathan, E., Fraser, J., \& Thompson, L. S. (1992). What determines demand for freight transport, Policy Research Working Papers, Transport, Infrastructure and Urban Development. The World Bank.

ECD. (2006). Decoupling the Environmental Impacts of Transport from Economic Growth.

European Commission (2011). EU transport in figures: Statistical pocketbook. Luxembourg.

Kimenyi, M.S., Routman, B., Westbury, A., Omiti, J., \& Akande, T. (2012). Background paper- CAADP at 10: Progress toward agricultural prosperity. CAADP at 10: Progress toward Agricultural Prosperity. Washington DC: Brookings Institution.

Mckinnon, A. (2006). The decoupling of road freight transport and economic growth trends in the UK: An Exploratory Analysis. Logistics Research Centre, Heriot-Watt University, Edinburgh.

Mckinnon, A. C. (2007). Decoupling of road freight transport and economic growth trends in the UK: An Exploratory Analysis. Transport Reviews 27(1), 37-64.

Meersman, H., \& E. Van De Voorde. (2003). Decoupling of Freight Transport and Economic Activity: Realism or Utopia? 16th International Symposium on Theory and Practice in Transport Economics: 50 Years of Transport Research: Experience Gained and Major Challenges Ahead, Budapest, European Conference of Ministers of Transport.

Rommerskirchen, S. (2003). Decoupling of economic and transport growth: Background, findings and prospects. 16th International Symposium on Theory and Practice in Transport Economics: 50 Years of Transport Research: Experience Gained and Major Challenges Ahead, Budapest, European Conference of Ministers of Transport.

Tapio, P. (2005). Towards a theory of decoupling: degrees of decoupling in the EU and the case of road traffic in Finland between 1970 and 2001. Transport Policy 12(2), 137-151.

OECD. (2001). Policies to Enhance Sustainable Development, OECD, Paris. The European Commission's 2001 White Paper on Transport.

United Nation Economic Commission for Africa report (2010).

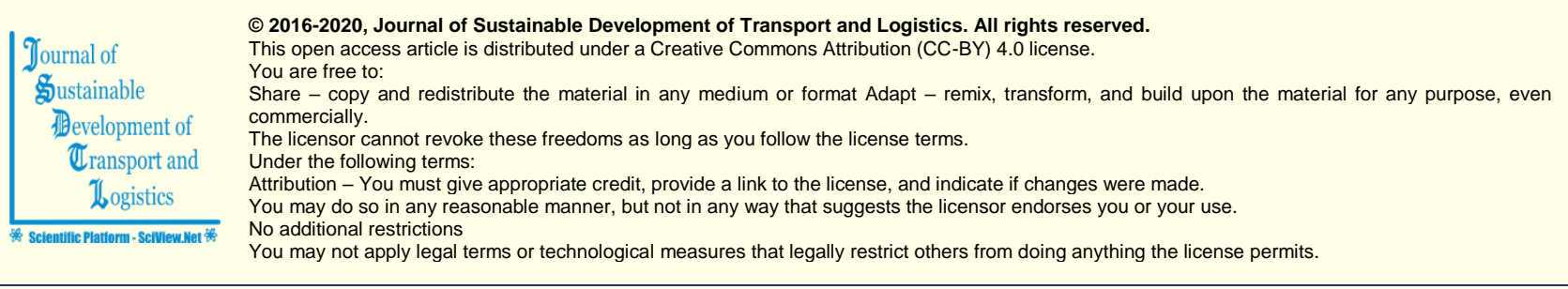

Journal of Sustainable Development of Transport and Logistics (ISSN: 2520-2979) is published by Scientific Publishing House "CSR",

Poland, EU and Scientific Publishing House "SciView", Poland, EU

Publishing with JSDTL ensures:

- Immediate, universal access to your article on publication

- High visibility and discoverability via the JSDTL website

- Rapid publication

- Guaranteed legacy preservation of your article

- Discounts and waivers for authors in developing regions

Submit your manuscript to a JSDTL at https://jsdtl.sciview.net/ or submit.jsdt|@sciview.net 